ISLLAC

Journal of Intensive Studies on Language, Literature, Art, and Culture

Vol. 1 No. 1 September 2017

\title{
UNFOLDING VALUES OF JAVANESE CULTURAL WISDOM IN JIDOR SENTULAN JOMBANG: AN ETHNOLINGUISTIC STUDY
}

\author{
Susi Darihastining \\ Maryaeni \\ Indonesian Literature Department of STKIP PGRI Jombang \\ e-mail : s.nanink@gmail.com
}

\begin{abstract}
Study on language and culture put language as an act and means to fulfill the act. As an act and the means, language conveys many functions. Ideology functions are one of language function resulted from an assumption that particular language feature conveys ideology dimension of a society, in Santoso (2007). Ideology is a reflection of social values which are a consensus. Jidor Sentulan is a literary performance done through dialogic narrating through which tradition and culture are held firmly. This study aimed at describing ideology function of Jidor Sentulan in Jombang. Ethno linguistic analysis describes some language features to reveal values of Javanese cultural wisdom as the ideology of people in Jombang. Results of the study found several language features that represent the values of Javanese cultural wisdom found in Sentulan Jidor of Jombang, they are: (1) lexical process includes (i) lexicalization, (ii) less lexical, and (iii) more lexical; and (iv) modalities, implicature, and terms of address. (2) Awareness functions include (i) function of friendship and brotherhood, (ii) function of the spirit and hard work, (iii) function of social care for the environment, and (iv) function of ideology and religious. The results of the study might be useful to preserve values of local wisdom.
\end{abstract}

Keywords: lexical (less and more in lexical terms), ethnic linguistics, local wisdom

\section{INTRODUCTION}

Jidor is a traditional Javanese verbal art. It is performed in traditional ceremonies to celebrate important stages of life such as birth, circumcision, and marriage. Imron (2000) conforms when neo liberal policy and tradition enter an art world, folklore will be left behind. Nevertheless, cultural study support and closely related with language development language. The Cultural study also interconnected 
ISLLAC

Journal of Intensive Studies on Language, Literature, Art, and Culture

Vol. 1 No. 1 September 2017

with social meaning. Besides, Fowler (1986:147) mentions that language plays important role in classifying speaker's experience or perspective language in Halliday ideology and functional experience, in (Santoso, A.2007).

The result of observation describes that verbal culture brings a contribution in shaping characteristics of a particular ideology of a society. In a society, the characteristics are strong to be valued, and inherited from generation to generation. In addition, the characteristics which reflect the ideology value are usually reflected in the verbal text through its language features.

In order to obtain ideology of a text, we can analyze its language features which can be used to structure the ideology conveyed,in Santoso, A.2007). Research questions are raised to observe the phenomenon of language features, how values of Javanese cultural wisdom as the ideology of Jombang people occur in Jidor Sentulan Jombang. Jidor Sentulan in Jombang presents values of Javanese culture that fall within the functions of consciousness and reflected in its lexical process. The process of lexical includes (1) lexicalization, (ii) less lexical, and (iii) more lexical; and (iv) modality, implicature, and terms of address. (2) Awareness functions include (i) function of friendship and brotherhood, (ii) function of the spirit and hard work, (iii) function of social care for the environment, and (iv) function of ideology and religious.It encourages researchers to examine and lift the verbal art performance in Jombang, East Java. Besides, Jidor Sentulan is unique. It is different from other Jidor in java which does not come in the narrative, Jidor Sentulan Jombang occurs in the narrative. Koentjaraningrat (2003) stated that cultural value system served the highest guideline for the behavior of human. These values have been inherent to every member of the community that it is difficult to be replaced or modified in a short period of time (Sukidin, Basrowi, and Wiyaka, 2003: 10-11). Oral performance is dynamic over the time. According to Ong (1978), the oral performance is developed from primary to the secondary oral performance. Finnegan (1992: 131) describes that the oral tradition is sometimes interpreted as an unwritten tradition (including monuments, religious sculptures, or paintings in the church), sometimes 
ISLLAC

Journal of Intensive Studies on Language, Literature, Art, and Culture

Vol. 1 No. 1 September 2017

also interpreted as a tradition or some traditions manifested through the word. The narration is defined by Herman \& Vervaeck (2001: 80) as the way a story is told.

"It is concerned with formulation - the entire set of ways in which a story is actually told. While the story is not visible in the text, narration involves the concrete sentences and words offered to the reader."

Meaning of narrative for human culture, according to Fluderik (2006:1-2 ) can be seen from the fact that their myths always talk about their origin, also the image of " the people in the future. Fowler (1986) and Fairclough (1989) stated that the relation and function of the textual construction of social condition, institutional terms, and ideology were in the production and the acceptance process.

\section{METHOD}

This study aimed at recording back constructions of Jidor Sentulan in the poetic narrative perspective, which includes; (1) the representation of the value of character education in poetic narrative functions contained in Jidor Sentulan in Jombang and (2) the process of lexical which covers lexicalization, (ii ) more lexical, and (iii) less lexical. Ideology in the text, according to Fowler $(1985 ; 1986)$, can be analyzed through various features of different lingual used in structuring ideational meaning in Santoso (2007). Thus, the purpose of this study is to reconstruct the traces of Jidor Sentulan and enrich ethnolinguistic study in Indonesia. Ethno linguistic is used as a theoretical orientation. Ethnolinguistic analysis model used is the Fowler analysis model, because this analysis model formula is able to solve the educational aspects of the representation of the character values in the function of poetic narrative contained in Jidor Sentulan in Jombang. The data source of this research is Jidor Sentulan performed in Bongkot village, Peterongan Jombang, East Java. Jidor Sentulan's artists are informants of the study who gave information. The setting of the research is a source of information in the form of the cultural sociology of the verbal art performance, Jidor Sentulan. Data obtained either through 
ISLLAC

Journal of Intensive Studies on Language, Literature, Art, and Culture

Vol. 1 No. 1 September 2017

observation and interviews and classified according to the characteristics of each data. Data of the verbal art performance which was in the form of transcripts of recordings were grouped by similarity form, presenting ideology in the text and the representation of the value of character education in poetic narrative functions in Jidor Sentulan in Jombang. The transcribed data were grouped and analyzed using Fowler (1985-1986) analysis model.

\section{FINDINGS AND DISCUSSION}

\section{Lexical Process}

To view the ideology of the text, according to Fowler $(1985,1986)$, we can analyze the various features of different lingual used in structuring ideational, namely (1) the process of lexical and (2) the modalities. The lexical process includes (1) lexicalization, (2) less lexical, and (3) more lexical in Santoso (2007). Lexicalization related to the existence of a word for a concept, for example, about overgeneralization or consistent use of terms that both contain certain social meaning.

\section{Quotes (3.06)}

"Mbem bedug tengahe lingsirtak rewangi panas-kepanasan, udan kodanan. Tak rewangi mlebu alas metu alas, sikil mlentung sak jagung-jagung Mbem”. (MNJS.KMA.D6).

\footnotetext{
"Mbem, in the middle of the hot mid-day, caught in the rain. I was willing to go in and come to the jungle and the feet became swollen like the corns Mbem"
}

"bedug tengahe lingsir" (at the day in the burning sun). The word "tengahe" (the middle of the day) convey the meaning of expectation for God's help ("tumenga ngarep-arep pitulungane' sing luwih kuwasa"). '..lingsir.'’ means burning sun. Simple lexicalization happened in Jidor Sentulan Jombang which reflected the spirit and belief of 
ISLLAC

Journal of Intensive Studies on Language, Literature, Art, and Culture

Vol. 1 No. 1 September 2017

expecting God's hand. The less lexical was shown with respect to a situation in which there is an obstacle in terms of a set of specific concepts, such as replacement of complex expressions (redundant) that is being used.

\section{Quote (3.13)}

“... mulane Mbem manungsa iku minangka urip-uripan yaah uripana, aja duwe wiring lan isin ayo podo nyambut gawe sak mlaku panggon, sing penting kenek digawe tuku lan nyukupi sandang kelawan pangan. Margo anak putu kate kanggo ujian lak ngono Mbem”.'(MNJS.KMA.DO14)

“...Therefore, to survive your life, one should make a living, he must support himself, do not need to have a sense of shame in choosing a particular job. Working with any nature to afford life and provide food for the family, for the children and the grandchildren, Mbem...”

More lexicalization is a use of the term to a particular object. Data utilize hyperbole style or synonyms, as follows;

\section{Quotes (3.17)}

"Mbem tak rewangi kelara-lara udan adus kringet Mbem, saking aja dingersula ayo padha disenengake dulur-dulure dhewe thaa yaa. Lak.ngana Mbem...”.(MNJS.KMA.MK18).I

" Mbem (although sweat-bathing) I did everything in his power and effort, Mbem not easy lamented let's entertain these brothers you know, don't you? Mbem ...."

"Saklimah utawarong klimah, dulur tuwa sing kayaaku,sabejad-bejade rai, sarusak-rusakelambe ayo padhadigugu ucap sakecap...." (APGSW.04) 
ISLLAC

Journal of Intensive Studies on Language, Literature, Art, and Culture

Vol. 1 No. 1 September 2017

"less or more, older people like me, the worse face I get, the worse clothes I

wear, let's listen what I told you"

\section{Quotes (9.14)}

"...mulane sadulur tuwek sadulur pucet dulur tuwa aja eman-eman segasakepel, ajak(aja) angen-angen bandeng satugel...". (APGSW.06)

“...Therefore, when you are with your older sister or brother, you have to give each other and don't be stingy in giving something or keep counting although it is only a handful of rice and a slice of fish".

Life, in the perspective of Jidor Sentulan, is actually done in pleasure without any sense complaining about the intention of pleasing others. More lexical using hyperbole style to create a lasting impression in the above example of the word "sweat-bathing" is actually just sweating in general, but to give the impression of excessive effort then use the vocabulary "sweat-bathing".

The words 'sabejad-bejade rai', 'sarusak-rusakelambe' dan 'sadulur tuwek sadulur pucet dulur tuwa' also give stress in using language styles of hyperbole which the meaning is giving a suggestion.

\section{Modality}

Modalities are linguistic features which show the level of commitment or attitude of the speaker towards the proposition that they utter or attitudes toward hearer. Kinds of modalities in certain languages can inform the level of commitment. In Indonesian, for example, informing that someone can declare desires, expectations, invitations, orders, and prohibitions in (Santoso: 2007). 
ISLLAC

Journal of Intensive Studies on Language, Literature, Art, and Culture

Vol. 1 No. 1 September 2017

\section{Quotes (7:10)}

"Ayo muga-muga bocah immane besok isaa taat immane, apik

lan dewasa isa disumerep marangwong tuwa, isa eling kang iman, isa laksanakna ibadahmarang Kang Maha kuasa Mbem”.'(FNJS.ID1).

"Let's hope this kid will be an obedient, faithful, mature, respectful, and diligent to worship the Almighty God".

Except (FNJS.ID1) indicates the modality which showed the suggestion about the way of the attitude of children who were circumcised later. Although the format is prayer there are words of hope and functions. The words are: faith, worship and respect the elderly.

“...mulane Mbem, saklimah utawarong klimah, dulur tuwa sing

kayaaku, sabejad-bejade rai, sarusak-rusakelambe ayo padhadigugu ucap sakecap

dulur tuwaya repot dulur tuwa yo kerepotan”.(9.11) (SNJS.PP4)

This narrative text shows an explanation at glance to someone who is younger to listen to the older people's advice. The moral value is respecting older people.

“...Dulur Mbem tega laware... rabtega banyune rah tega lorane ora tega pạtine”. (9.12) (SNJS.PP5)

"...Brother or sister Mbem, he or she will dare in your sickness but they will not dare in

your death".

The meaning of the statement is more explained in detail that the brotherhood cannot be separated from water. The water cannot be cut and always flow in the lower places or the narrative text can be stated that it has a commitment in having brotherhood till tomorrow ever after. 
ISLLAC

Journal of Intensive Studies on Language, Literature, Art, and Culture

Vol. 1 No. 1 September 2017

\section{Quotes (7.11)}

"Isa medhot dulur padha kara isa medhot banyu"(FNJS.ID2)

The statement above showed the modality. It showed the possibility of being apart from the relationship and the family tree because of the action itself.

"Therefore Mbem, a buman being must remember and remind that we must live together for a living, giving to older people without counting or don't be stingy to other people even your own brother".

As a human being, we must remember and remind ourselves not to be stingy to give a handful of rice and a slice of fish. The narrative text has also the same content such as in the following explanation

"...Ayo yen ana dina becik ayo padba sowan silabturrobhim”. (9.14) (SNJS.PP7)

“...Let's visit each other when there is the good occasion of time".

The core of this narrative text was visiting each other. Visiting each other in the perspective of Jidor Sentulan was fulfilled with reminding each other, taking care, and giving each other. The benefit of visiting each other was explained more with the following sub statement:

"...Mulane ayo padha dijaga kerukunan, ayo padha dijaga kerukunan salingkungan, satangga keluarga digedekna kerukunan, yen golek utangan gampang” (6.15) (SNJS.PP8).

“...Therefore, let's have the relationship, let's save the relationship in our surrounding, the neighborhood to be easier in borrowing money"

From the several data, it can be concluded that based on the modality indicator, namely visiting each other like in the above explanation and there is contextualization to have a good relationship to survive the family union, giving hope, and respecting older people. 
ISLLAC

Journal of Intensive Studies on Language, Literature, Art, and Culture

Vol. 1 No. 1 September 2017

\section{Implicature (Hidden Meaning)}

\section{Functional Meaning of Poetic Narration of Jidor Sentulan}

In this section, results of the analysis of the functions of poetic narration of Jidor Sentulan for people in Jombang are described. The social function, in Ethno linguistic perspective, can be discussed thoroughly from performance aspects to poetic narrative or linguistic aspects, but this paper is only discussed in the representation of the value of character education in poetic narrative contained in Jidor Sentulan in Jombang whose function of values character educational characters are categorized into three types, namely (1) the function of consciousness or awareness including the function of friendship and brotherhood, (2) the function of the spirit and hard work, (3) the function of social care for the environment, and (4) function of ideology and religious.

\section{Function of Awareness Meaning}

Awareness or tolerance function is as a story or a play has the function to spread awareness in some form to the intended audience of the story. A form of awareness is exactly what becomes important in the construction of a story, so as to form values of character values of education of the audience. Awareness in this regard relates to the mindset and psychological condition of a person or a society. A performance on the stage is to entertain the audience but in the behind of an entertaining performance, it is constructed to arrange the values of individuals in the community to a community of people able to live together in a harmony which is supported by a system of strict norms. The rules in society are not granted to became truth in a society but require a smooth penetration into the minds of the public individual mind. Therefore, planting consciousness or awareness through narrative can be packaged in a staging. Contextual meaning contains some awareness, namely: awareness of some awareness functions include the function of the spirit and hard work, the function of social care for the environment, and ideology function and religious function. 
ISLLAC

Journal of Intensive Studies on Language, Literature, Art, and Culture

Vol. 1 No. 1 September 2017

\section{Function of Hard Working Meaning}

The spirit of hard work is an attitude that is in accordance with Javanese values in the statement of "sepi ing pamrih, rame ing gawe" (a lot of sincere work). Narrative Jidor Sentulan also provides an overview of the Java philosophy in different forms

"...mulane Mbem manungsa iku minangkaurip-uripan yoob uripana, aja dhuwe wirang lan isin ayo padha nyambut gawe sak mlaku panggon." (FNJS.KDR.SB1)

“...if it so Mbem, if a man cannot feel alive (work), so work, do not feel ashamed,

Survive in the life, work, do not have any shame let's work wherever and whatever the work is..."

"In the exception (7:02), narrative (FNJS.KDR.SB1) directs the audience of Jidor Sentulan to gain awareness that contains values of Javanese wisdom as education, i.e. to meet the needs of human life, one must work hard in any form without shame and pride. The existence of the phrase 'ojo dhuve wirang lan isin' has meant that a man should not put oneself in prestige and feel ashamed of how he makes money. This basically triggered by the tradition of people who feel ashamed of several kinds job and take pride of the other kinds of occupation. The field observation indicates that society owned by Jidor Sentulan still leave traces of shame and pride in a particular job. Especially the occupation which is in the view of the sociological community is low, such as rickshaw drivers, the seller leaves, wood sellers, brick layer, etc. (Observation, March 21, 2011 ). Jidor Sentulan describes an invitation to the community to work hard despite the kind of occupation. 
ISLLAC

Journal of Intensive Studies on Language, Literature, Art, and Culture

Vol. 1 No. 1 September 2017

\section{Function of Social Care Meaning}

The values of Javanese cultural wisdom is embedded in the context of Javanese culture is so complex. Even so very complex, a verbal art performance tries to remind the audience to live a better life. One should not easily complain, but live the life happily.

Quotes (7.04) "Mbem, yen mula kowe aja gampang ngersola ayo padha disenengake dulur-dulure dewek tho ya." (FNJS.KDR.MK1).

Quotes (7.04) “that is why Mbem, you don't complain too much, instead let's make others happy".

The exception of (FNJS.KDR.MK1 ) implies that the living and the profession as an actor is heavy, but do not easily complain because entertainer's task is to make others happy. Cognitively, value brought by the narrative (FNJS.KDR.MK1) is the delivery of a concept on how to make you be happy. Make yourself happy means being able to live a life as it is without complaining, trying instead to make others happy. The concept is illustrated in Jidor Sentulan like an entertainer that in any psychological condition he should be able to make others happy. Such concepts can be regarded as the concept of 'giving' and not 'asking'. Thus, the awareness that can be learned is that if people want to be happy, then give happiness to others without complaining.

Some forms of consciousness is a collective consciousness that contains the values of character education, trying spoken by the messengers through narratives in Jidor Sentulan . A staging that has been rooted in community life is usually caused because the play has more value or meaning for the community. 
ISLLAC

Journal of Intensive Studies on Language, Literature, Art, and Culture

Vol. 1 No. 1 September 2017

\section{Quotes (8.01)}

"Tak rewangi mlebu alas metu alas, sikil mlentung sa jagung-jagung Mbem.

Sikil rasane gatel-gumatel, yo ngeneiki wong rasa-rasane wong dhuwe tanggung jawab utawa titipan sakanca Mbem, Kumbang Semendung sarombongan dolan.”(FNJS.KSR.TJ1)

"I am willing to go in and go out of the jungle and my feet are sore like corns Mbem, the feet are itchy and get bigger like corns, this is the responsibility of the message of friends Mbem, the bees of Semendhung played."

The responsibility in the narrative text is the responsibility of Kumbang Semendung show and friends or the responsibility in Jidor Sentulan show from one to another street. It indicates that Jidor Sentulan show is 'responsibility in friendship' or responsibility together. The narrative text gives a solution for the spectators that 'togetherness' or cooperation is the truth that must be kept by the people of Sentulan, it can be also stated that it is the symbol of care to survive the culture in the surrounding of the people in the village of Jidor Sentulan.

\section{Function of Ideology and Religious Meaning}

The function of ideology means that narratives often contain concepts of life belief and even belief in God's life. This is proved by many scriptures that basis it is a story or play about the character or prophet with the belief to God is able to conquer all hurdles along with a variety of teaching kindness.

\section{Quotes (7:10)}

"Ayo muga-muga bocah immane besok isaa taat immane, apik lan dewasa isa disumerep marangwong tuwa, isa eling kang iman, isa laksanakna ibadabmarang Kang Maba kuasa Mbem”.(FNJS.ID1) 
ISLLAC

Journal of Intensive Studies on Language, Literature, Art, and Culture

Vol. 1 No. 1 September 2017

"Let's hope this kid tomorrow obedient and strong faith, good and mature, respect the elderly, can be diligent to worship the Almighty".

\section{Quotes (8.12)}

"Tak sununnakemarang Gusti Allah, bismillah birobmannirrobim...salam musalamu alaikum salamku sing tak tujuake marang Gusti Allah sing manggane ing telenging swarga, klisenen martabat lima pancer disekseni para nabi, parawali, lan bapa Adam dan ibu Hawa”. (FNJS.ID3).

“I ask the God Allah, Bismillah hirrohmanirrohim...salam musalamu Alaikum, I greet Allah in the heaven with the five glory light and is seen by father

Adam and mother Hawa".

This statement gives a description that the people of Jidor Sentulan believed in God Allah SWT at that time, although it is still interference with the Javanese ideology or 'kejawen'. It can be proved that the belief in God Allah from the five glory light 'martabat lima pancer' (which have a meaning in Javanese field). It is also explained that the word 'sedulur papat' is an explanation of a mother who bears a baby will have a painful feeling called mamarti, the baby was born with her heart. Then the baby in the stomach will be the candidate of a human. After the thing called yellow abdomen, red blood, and the black umbilical cord. The painful feeling, the abdomen, the blood and the umbilical cord are named sedulur papat in the Javanese mythology. The fifth thing is pancer, namely the candidate of the baby who will become human. Besides, there is a belief in the clerics that the clerics in Muslims who spread Islam in Java especially for the clerics of Sunan Kalijaga (Interview, 10 October 2011).

The parents are the ocean that can give the answer for life and as the vice God in this world to get the blessing. Jidor Sentulan tries to represent it such as in this following statement. 
ISLLAC

Journal of Intensive Studies on Language, Literature, Art, and Culture

Vol. 1 No. 1 September 2017

\section{Quotes (8:03)}

"...mulane Mbem, saklimah utawa rongklimah, dulur tuwa sing kaya aku, sabejad-bejate rai, sarusak-rusake lambe ayo padha digugu ucap sakecap" (FNJS.KDR.MT1)

“...therefore Mbem, one or two older brother or sister like me, although I am bad in the face and in my words, you should listen to me.”

How good the present values of Javanese culture in this narration. It shows that we must respect the parents who bear, take care, and educate us, and also respect our older brothers and sisters as the vice parents.

The concept of the values of Javanese cultural wisdom in the sense of brotherhood that is delivered by Jidor Sentulan is the concept of brotherhood as well as the Java community in general and philosophy. Fraternity price is very high so that no matter what happens you still brothers. Javanese people say "mangan ora mangan kumpul" (eating or not eating must be together). The term is a portrait of how the atmosphere of brotherhood in the Java community concept contains the values of character education itself. Whatever happens, keep gathering, whether or not there is food remains together. Therefore, presumably precisely described by Jidor Sentulan; that fraternity cannot be disconnected as when someone wants to cut off the water, but the water remains united. Biological relevance for the Java community is significant and cannot be separated.

The above narrative fragment has the nuance which expresses the concept of community actors of Jidor Sentulan in finding the meaning of life. The quote of Jidor Sentulan ( 3:14) " ... Minangka urip - uripan yaah uripana ... " ( MNJS.KMA.DO15) tend to give a discourse that when we are given the mandate to live by the power, then you should fill the life with truths of life. True life is a life that is filled with the 
ISLLAC

Journal of Intensive Studies on Language, Literature, Art, and Culture

Vol. 1 No. 1 September 2017

utmost effort, in the sense of doing something with all your heart. Those words occur in redundant.

\section{Terms of Address}

The term of address for the main character is named Mbem which can be seen in the data of FNJS.KDR.SB1, quotes (7.04) in FNJS.KDR.MK 1, quotes (3.06) in MNJS.KMA. D6, quote (3.13) in MNJS.KMA.DO 14, quotes (3.17) in MNJS.KMA.MK18.1 and also the term of address by using the word "bocab" which can be seen in the data of quotes (7.10) in FNJS.ID1. The word "Mbem" is used to show the vocative and close relationship and the word "bocab" is used to show that the subject is in the age of the young person.

\section{CONCLUSION}

Poetic narrative functions of Jidor sentulan convey values of Javanese cultural wisdom as the ideology of people in Jombang, specifically in educating the people can be seen in the terms of lexical process, modality, implicature and the terms of address. The values represent (1) Jidor Sentulan is a local citizen identity of Sentulan village, (2) Jidor Sentulan is the resource of customs and tradition with the use of particular language features, (3) Jidor Sentulan is a means of inherent values of Javanese local wisdom, both educational and ideological doctrine, and (4) Jidor Sentulan is a means of expression for Sentulan community.

In preserving the local verbal art performance, i.e. Jidor Sentulan, some suggestions are first addressed to officials of the education and culture as the government authority in education and culture, especially in Jombang. They should create policies that stimulate the performing arts Jidor Sentulan Jombang so as to reinforce the existence of local identity community. The policies can be in the form of either formal or informal socialization of Jidor Sentulan through education. This can strengthen young generation characters in holding the value of local wisdom. Secondly, further research can have an in-depth study of Jidor Sentulan to steeped Jidor Sentulan and Sentulan people's daily life. Jidor Sentulan is still needed to be 
ISLLAC

Journal of Intensive Studies on Language, Literature, Art, and Culture

Vol. 1 No. 1 September 2017

investigated from different perspectives, such as ethnographic perspective and performing arts. Other perspectives will possibly bring insight of traditional verbal art performance.

\section{REFERENCES}

Sweeney, A. (1987). A Full Hearing: Orality and Literacy in the Malay world. London: University of California Press, Ltd.

Arps, B. (1992). Tembang in two traditions: Performance and interpretation of Javanese literature. Southampton: Hobbs the Printers Ltd

Ayatrohaedi. (1986). Kepribadian Budaya Bangsa (local Genius). Jakarta: Pustaka Jaya.

Barker,C. (2000). Cultural Studies : Teori dan Praktik.Terjemahan oleh Nurhadi (2004). Yogyakarta: Penerbit Kreasi wacana.

Bogdan, R.C. and Biklen, S.K. (1998). Qualitative Research for Education: An Introduction to Theory and Methods. Boston: Allyn and Bacon.

Dananjaya, J. (1989). Fungsi Teater Rakyat bagi Kebidupan Masyarakat Indonesia.Dalam Sedyawati, Ed.y.1989 Ketoprak/Dagelan Siswo Budoyo sebagai Suatu Studi Kasus. Jakarta Selatan: Wedatama Widya Sastra.

Denzin, K.N. and Lincoln, Y.S. (1994). Handbook of Qualitative Research. Sage Publication.

Emzir. (2010). Metodologi Penelitian Kualitatif: Analisis Data. Jakarta: PT RajaGrafindo Persada.

Effendi, R. (1993). Tradisi Pembacaan Sinrilik dalam Masyarakat SukuBangsa Makassar di Sulawesi Selatan (Makalah). Jakarta: UniversitasIndonesia Jakarta.

Fairclough, N. (1995). Critical Discourse Analysis: the Critical Study of language. HarlowEssex: Longman Group Limited.

Fowler, R. (1996).On Critical Linguistics. Dalam Caldas-Coulthard, C.R. \& Coulthard, m. (Eds), texts and Practices: reading in Critical Discourse Analysis 9hlm 314). London: Routledge. 
ISLLAC

Journal of Intensive Studies on Language, Literature, Art, and Culture

Vol. 1 No. 1 September 2017

Gerstle, C.A. (2005). The Culture of Play Kabuki and the Production of Texts. E.Companion $0($ Online),retrieved from http:/wmw.oraltradition.go.id, on March $12,2012$.

Herman, L and Vervaek. (2005). Handbook of Narrative Analysis. Lincoln and London: University of Nebraska Press.

Ikram, A. (1980 \& 1981).Perlunya Memelibara Sastra Lama. Analisis Kebudayaan No.1 Thn.1. Abstrak diperoleh dari Inriati Lewa,et al,Sinrilik "Datumuseng", 1997, Abstrak No.10(1A) Februari UGM.

Imron, Z. (2000). Upaya Progresif dalam Menyelamatkan Kebudayaan Madura dari Gempuran Globalisasi (online) 27-7-2000.http:/ / nusasastra.blogspot.com,accessed in 17-4-2011.

Kabupaten. (2012) .Sejarah Jombang . http://jombangkab.go.id) accessed in 20 June 2012.

Koentjaraningrat. (1984). Kebudayaan Jawa.Jakarta: Balai Pustaka.

Nanang, et.al. (2012). Sejarah dan Budaya Jombang. Jombang: Dinas Pendidikan Kabupaten Jombang.

Ong, W.J. (1982). Orality and Literacy The Technologizing of the Word.USA.Published Methuen \& Co.

Pudentia, MPSS. (1998). Metodologi Kajian Tradisi Lisan. Jakarta: Yayasan Obor Indonesia.

Santoso, A. (2007).Jurnal Bahasa dan seni, Tahun 35. Nomor 1, februari. Jurusan sastra Indonesia, fakultas sastra, Universitas Negeri Malang.

Santoso, A. (2006).Bahasa, Masyarakat dan Kuasa: Topik-topik kritis dalam Kajian Ilmu Bahasa. Malang : Jurusan sastra Indonesia, fakultas sastra, Universitas Negeri Malang.

Sudikan, Y. S. (2001). Metode Penelitian Sastra Lisan. Surabaya. Citra Wacana.

Thailand Research Fund.(2009). Characteristics and Types of Community Knowledge.http://www.trf.or.th/News/Content.asp?Art ID=184 (February $15,2009)$

Wedhawati et.al. (2001). Tata Bahasa Jawa Mutakhir. Jakarta. Pusat Bahasa. 